\title{
Transformation of Property Right as a Fundamental Right into Joint Property
}

\author{
Mg. lur. Inga Kudeikina \\ Latvia, Riga Stradins University, Division of Doctoral Studies \\ doctoral student in the study program "Law sciences" \\ ingakudeikina@inbox.Iv
}

\section{Doi:10.5901/mjss.2013.v4n11p441}

\begin{abstract}
Property rights are one of individual's fundamental rights that are considered absolute. In modern civilized world understanding of exhaustion of property rights is reduced to maximum protection of the third parties that is being accomplished by the encumbrances of property rights. One of them is joint property, the content of which constitutes a set of legal and factual conditions, and as a result the absolutism of property rights becomes relative. The state in the name of society promotes additional conditions for real division of joint property, because it considers it as an exhaustion of property rights that affects municipalities in which the item for division is situated, as well as that affects interests of the population. The research is conducted with an aim to determine the legitimacy and proportionality of the restrictive normative acts in relation to property rights as fundamental rights. Descriptive and analytical methods are used in the research. As a result of this research, the author came to a conclusion that additional preconditions set by the state and the municipalities for the exhaustion of property rights in joint property are disproportionate for the property rights as fundamental rights. It is manifested, first, as a restriction for the exhaustion of individual's property rights in relation to equivalent individuals- in common items for other co-owners (horizontal vector), and second, as a restriction for the exhaustion of property rights in common items for all co-owners in relation to the third parties (vertical vector). The existing normative regulation is not satisfactory, and that is supported by the court proceedings in the Constitutional Court of the Republic of Latvia. Procedural arrangements for the division of joint property and their legal consequences do not affect the rights of other individuals; therefore, such amendments of normative acts are necessary that would separate the real division of joint property as a legal act that would not be bound to and made dependant on those possibilities of the real estate use that are created as a result of division.
\end{abstract}

\section{Introduction}

In this Article the author focuses on the causes of transformation and ways of manifestation of property rights as individual-specific fundamental rights into joint property. The theory of the Latvian civil law construes the Joint Property as the power restriction of the owner (i.e.co-owner) of property rather than that of the property (Sinaiskis 1996). The question is significant, because it is the "property right that ensures every person's freedom in the proprietary legal field and the possibility to acquire and use financial benefits, and dispose of them." (Grūtups \& Kalninš 2002). The problem under research will always be topical. The development of society, in the broader sense, and the development of the law institute, in the narrower sense, take place continuously and in a democratic country it is important to let it happen in its full range, according to the fundamental rights inherent to person.

This research was conducted in order to ascertain the legitimacy of the laws restricting real distribution of joint property and their proportionality in relation to the property right as a fundamental right.

The author uses the well-established research methods: descriptive and analytical. The content of laws is revealed by the descriptive method, using grammatical and structural methods of interpretation of laws. The analytical method was used for the analysis and evaluation of legal scientific opinions in conjunction with the content the law. The research is based on national and foreign literature, legislation and case law.

\section{Research}

Property rights have long and deep roots in human rights and fundamental freedoms. The right to property is a constitutional right and an essential element of basic human rights.

In the doctrine of private law, the property rights are viewed as natural rights, as a true public liberty. In this sense, private property should be viewed as a form of expression of personal freedom. Without the institute of property rights and the laws that protect it, one cannot speak about human rights. Private property allows for freedom of economic and 
social relations, respecting general principles of human rights, such as equality and justice, and freedom of transactions.

The interpretation of national legislation is based on the principles defined in Section 17 of the Universal Declaration of Human Rights: "Everyone has the right to own property alone as well as in association with others. No one shall be arbitrarily deprived of his property." ${ }^{1}$ On the European level, Section 1 of the First Protocol of the European Convention on Human Rights contains such a provision: "Every natural or legal person is entitled to the property. No one shall be deprived of his possessions except in the public interest and subject to the conditions provided for by law and by the general principles of international law." ${ }^{2}$ Another elaborate defence mechanism is set by the norm contained in the first paragraph of Section 17 of the European Union Charter of Fundamental Rights: "Everyone has the right to own, use, dispose of and bequeath his or her lawfully acquired possessions. No one may be deprived of his or her possessions, except in the public interest and in the cases and under the conditions provided for by law, subject to fair compensation being paid in good time for their loss. The use of property may be regulated by law insofar as is necessary for the general interest."3

Latvian legislation is linked to the international laws listed above. The Constitution of the Republic of Latvia contains specific property protective regulations: "Everyone has the right to property. Property may not be used against the interests of society. Property rights may be restricted only in accordance with the law. A forced alienation of property for the needs of society is permissible only in exceptional cases on the basis of an individual law, for fair compensation."4

To summarize, one would agree to the conclusions of the Constitutional Court of the Republic of Latvia that by nature and by its generality the property right is one of the most fundamental human rights, which can be and may be restricted only in exceptional circumstances and only on the bases of law. However, property rights should not be regarded as absolutely inviolable, because they not only serve the interests of the owner, but they should also serve the public interest. ${ }^{5}$

Restrictions in the public interest are also reflected in joint property. Joint property is a complex type of property, where the co-owners are mutually subject to concerted expression of will, according to the Section 1068 of the Civil Law, as it is allowed to handle the object of a joint property, on the whole, as well as its individual parts, only with the consent of the co-owners ${ }^{6}$, and also there are conceptual limitations to certain transactions for the public good. Section 1074 of the Civil Law provides that "None of the joint owners may be forced to remain in jointly owned property, provided that it is not provided otherwise in the provisions under which the joint ownership is established; on the contrary, each joint owner may at any time require a division." Real distribution of joint property is a private law act. However, the current legislative framework has established procedures, where the co-owners are not absolutely free when addressing the real distribution of joint property, and they, in their agreed expression of will, should follow the restrictions for the good of society. What is the necessity and proportionality of the restrictions set out?

It is an uncontested allegation that any restriction of property rights must be as careful as possible. In this regard, one has to agree the opinion that "by interpretation of the rights set out in Section 105 of the Constitution and in Section 1 of Protocol 1 of the Convention, it can be concluded that the state has the right to restrict an individual's right to ownership, provided that:

1. the restriction of property rights is the law;

2. the ownership restriction serves to protect the rights of other persons or the general interests;

3. if the burden put on the person, whose rights are affected, is commensurate (proportional) to the benefit to society as a whole and there are no other solutions that would be more appropriate and less interfering with the individual right." (Anspak 2012)

The prerequisite for a real distribution of real estate is, certainly, the agreement of co-owners, but the real distribution can be carried out only on condition that it complies with the requirements of the local land use (spatial) plan, including with those on a minimum of newly created parcels. The spatial planning can be recognized as one of the tools

\footnotetext{
${ }^{1}$ General Declaration of Human Rights. Available at: http://www.humanrights.lv/doc/vispaar/vispcd.htm (looked up on 31.05.2013.)

${ }^{2}$ First Protocol of the European Convention on Human Rights. Available at: http://www.humanrights.lv/doc/regional/eck1prot.htm (looked up on 31.05.2013.)

3 European Union Charter of Fundamental Rights. Available at: http://eur-lex.europa.eu/lv/treaties /dat/32007X1214/htm/ C2007303LV.01000101.htm (looked up on 01.06.2013.)

4 15.02.1922 Law " Constitution of the Republic of Latvia" ("LV", 43, 01.07.1993.) [came to force 07.11.1922.] with amendments

5 Judgement of the Constitutional Court of the Republic of Latvia of 20.05.2002 to the case Nr.2002-01-03. "Latvijas Vēstnesis", 75 (2650), 21.05.2002.

${ }^{6}$ The Civil Law. Substantive rights. Adopted: 28.01.1937. Published: "Valdības Vēstnesis", 44, 24.02.1937.

7 ibid
} 
for aligning the individual and the community interests. It is a way to observe the public interest in the use of the real estate. Section 2 of the Law "Spatial Development Planning Law" of 13.10.2011 states: "The purpose of this Law is to attain such spatial development planning that would raise the environmental quality, ensure sustainable, effective and rational utilisation of territories and other resources, as well as purposeful and balanced development of economy." ${ }^{8}$ With the aim to accumulate and manage information about all immovable properties on the national territory, their handling and owners, the National Real Estate Cadastre Law entered into force in Latvia on 1 January 2006. ${ }^{9}$ This Law introduced a requirement leaving a significant impact in the future on the distribution of real property, that is, in accordance with Section 9 of the Law "A purpose of use of real estate and the land area under the jurisdiction of the purpose of use shall be determined (...)". It should be concluded that the real estate and consequently the adherent to it land area that do not have a determined purpose of use cannot exist anymore.

The right to determine the purpose of use of the real estate and the land area under the jurisdiction of the purpose of use is allocated to local governments. The local governments have a discretional power in determining the content of spatial planning, which also implies the right to determine the generally applied requirements for real distribution of real estate. This follows from the second paragraph of Point 1 of Section 14 of the Law "On Local Governments" of 19.05.199410, according to which the local authorities are required to "develop local area development programmes and spatial plans, to ensure the implementation of the spatial development programme and administrative supervision of the spatial plan." In practice, this leads to the situation that each of the nine cities of the republic significance and the hundred and ten counties ${ }^{11}$ has different requirements for the real distribution of real estate as to the minimum allotted parcels.

Chronologically the next law concerning the distribution of the real property is the "Land Survey Law" of 14.09.2006.12. With the objective of promoting land readjustment, this Law introduced the requirements not provided by the Civil Law. One cannot find there any mutual continuity and supplementing of legal norms, because the property originally is a private institute, which would require some references and links to the Civil Law. In accordance with paragraph one of Point 3 of Section 8 of the Law, the land use planning project is to be developed also for the division of land parcels, also those included in a joint property. In turn, paragraph one of Section 15, according to which "Joint holders may not request a division of a land parcel present in a joint property into actual shares, if the land parcels to be separated do not conform to the territory utilisation and building provisions specified by the local government, as well as to the other cases specified in the regulatory enactments" does not conform with the sense of the provisions included in Sections 1074 and 1075 of the Civil Law.

Taking a systemic look at the laws and regulations relevant to the real distribution of joint property, it should be concluded that the possibility of real distribution of joint property is determined by:

1. the intended use of the real estate created in the result of the distribution;

2. the territorial belonging of the real estate created in the result of the distribution.

There are no sufficient legal grounds that the law relating to spatial planning is automatically extended to all transactions in the division of real estate. Above all, the distribution of joint property means the termination of the joint property. It is an implementation of a property right, the reason of which cannot be automatically considered construction, transformation or any other activity that affects the environment, where public interest should be observed. The legal act, in the result of which several properties with a single owner are formed from a single property with multiple owners does not in itself affect the lawful interests of other persons and do not affect the public needs. But the burdens on the procedure of real distribution or even its complete impossibility due to the above reasons (impossibility to ensure the minimum area) substantially limit the subject's property right and, obviously, reduces the value of the real estate, because co-ownership is a burden which, compared to the unitary property, is harder to sell, more difficult to manage and so on. State policy in the field of real distribution of joint property should be reviewed, because the first Article of the First Protocol of the European Convention on Human Rights "provides for the state responsibility for interference with the property rights, if such intervention results in lower economic value of a property"13

\footnotetext{
8 13.10.2011 Law "Spatial Development Planning Law", "Latvijas Vēstnesis", 173 (4571), 02.11.2011.

${ }^{9}$ 01.12.20105 Law "National Real Estate Cadastre Law", "Latvijas Vēstnesis", 205 (3363), 22.12.2005., "Zinnotājs", 1, 12.01.2006.

10 19.05.1994 Law "On Local Governments" "Latvijas Vēstnesis", 61 (192), 24.05.1994., "Zinotājs", 11, 16.06.1994.

${ }^{11}$ Data available at: http://www.varam.gov.lv/lat/darbibas_veidi/pasv/kont/?doc=13066 (looked up on 11.06.2013.)

12 14.09.2006 Law "Land Survey Law", "Latvijas Vēstnesis", 157 (3525), 03.10.2006., "Zinnotājs", 20, 26.10.2006.

${ }^{13}$ Theory and Practice of the European Convention on Human Rights. Third edition by P.van Dijk, G.J.H. van Hoof. The Hague-London-

Boston. Kluwer Law International, 1998, p.620
} 


\section{Conclusions}

In the result of the research the author came to the following conclusions:

1. in the case of joint property the property right of co-owners is subject to severe restrictions;

2. There are no single criteria in the country for newly formed real estate;

3. The public interest in the procedure of real distribution of joint property takes precedence over the rights of individuals, which leads to crucial narrowing of content of property right;

4. The state should be responsible for interference with property right, where because of the governmental restrictions the economic value of property is reduced.

In the rights of co-owners to actually divide a jointly owned real estate, the governmental intervention is inadequate for the legitimate aim pursued. The real estate division does not in itself undermine the public interest and does not violate the rights of other persons.

\section{Recommendations}

For co-owners to ensure reasonable and adequate implementation of their property rights, it is necessary:

1. Not to refer automatically the rules relating to land use planning to the real distribution of joint property;

2. When interpreting laws, the real distribution of joint property is to be considered as a way of termination of coownership and the purpose of use of the established property (parcel) should be decided after their establishment;

3. To determine single requirements for the real distribution of joint property in the whole territory of Latvia.

\section{References}

"LV", 43, 01.07.1993. [stājas spēkā 07.11.1922.] ar grozījumiem

01.12.20105. Law National Real Estate Cadastre Law", "Latvijas Vēstnesis", 205 (3363), 22.12.2005., "Zinọtājs", 1, 12.01.2006.

13.10.2011 Law " Spatial Development Planning Law ", "Latvijas Vēstnesis", 173 (4571), 02.11.2011.

14.09.2006. Law "Land Survey Law", "Latvijas Vēstnesis", 157 (3525), 03.10.2006., "Zingotājs", 20, 26.10.2006.

15.02.1922 Law Constitution of the Republic of Latvia"

19.05.1994. Law "On Local Governments" "Latvijas Vēstnesis", 61 (192), 24.05.1994., "Zin̨otājs", 11, 16.06.1994.

Anspaks, Raivis. Research and analyses of problems related to joint property (Dalïta īpašuma problemātikas izpēte un analïze).

Available at: http://www.tiesibsargs.Iv/img/content/dalita_ipasuma_problematikas_izpete_un_analize_raivis_anspaks_2012.pdf

European Union Charter of Fundamental Rights. Available at: http://eur-lex.europa.eu/lv/treaties/dat/32007XX1214/htm/ C2007303LV.01000101.htm

First Protocol of the European Convention on Human Rights. Available at: http://www.humanrights.lv/doc/regional/eck1prot.htm General Declaration of Human Rights. Available at: http://www.humanrights.Iv/doc/vispaar/vispcd.htm

Grūtups, A., Kalniņš, E. Comments to the Civil Law. Part Three. Substantive rights. Property.-R.:Tiesu namu aǵentūra, 2002.

Judgement of the Constitutional Court of the Republic of Latvia of 20.05.2002 to the case Nr.2002-01-03. "Latvijas Vēstnesis", 75 (2650), 21.05.2002.

Sinaiskis, V. Outlook of civil rights in Latvia: the substantive rights. Liabilities. - R.: Latvijas Republikas Tieslietu ministrijas Tiesiskās Informācijas centrs, 1996 .

The Civil Law. Substantive rights. Adopted: 01/28/1937. published: 28.01.1937 in "Valdības Vēstnesis", 44, 24.02.1937.

Theory and Practice of the European Convention on Human Rights. Third edition by P.van Dijk, G.J.H. van Hoof. The Hague-LondonBoston. Kluwer Law International, 1998, p.620 